\title{
A Preliminary Exploration of Administrative Management in Agricultural Institutions of Higher Learning
}

\author{
Hailong SHAO ${ }^{1, a}$, Dongju DU ${ }^{2, b}$ \\ ${ }^{1}$ College of Engineering and Technology, Jilin Agricultural University, Changchun, 130118, China \\ ${ }^{2}$ College of Animal Science and Technology, Jilin Agricultural University, Changchun, 130118, \\ China \\ aemail: shaohailong1992@126.com, bemail:473352805@qq.com
}

Keywords: Agricultural Institutions of Higher Learning; Administrative Management; Characteristics; Problems; Suggestions

\begin{abstract}
Administrative management is an important part of management of institutions of higher learning. It plays a significant role in daily management of institutions of higher learning, undertaking internal coordination and management and guaranteeing smooth progress of various affairs in institutions of higher learning. Currently, there are still some problems existing in administrative management in institutions of higher learning, which call for immediate solution so as to improve their administrative management efficiency. Based on an overview of characteristics and problems of the current administrative management in agricultural institutions of higher learning, this paper puts forward specific suggestions to upgrade their administrative management.
\end{abstract}

\section{Introduction}

Internal affairs of institutions of higher learning mainly consist of academic affairs and administrative affairs. Similarly, their management is divided into two parts, academic management and administrative management. Academic management involves academic personnel and academic organizations, and administrative management serves academic management. Therefore, management of institutions of higher learning is both academic and administrative. Academic management and administrative management complement each other and form an indispensable part of the overall management in institutions of higher learning.

Administrative management in institutions of higher learning often involves a wide range of affairs related to teaching, scientific research and personnel. These departments, on the one hand should be able to command, organize and coordinate administrative management personnel; on the other hand, administrative management personnel should undertake the responsibility of evaluation and affirmation. All these tasks are highly professional, which drive administrative management in institutions of higher learning to increase its professionalism. Therefore, not only should administrative management personnel correctly use management methods, but also they should keep on learning relevant professional knowledge and skills. Only in this way can administrative management progress smoothly. ${ }^{[1]}$

Administrative management in institutions of higher learning often involves students, teachers and staff. Due to that, administrative management personnel should establish the people-oriented service awareness. Administrative personnel should master not only psychological characteristics, age differences and employment demands of students, but also academic and scientific research ability, instruction conditions, teaching atmosphere, payment package and opportunities of further study of teachers. Only in this way can teachers' teaching enthusiasm be fully stimulated and their worries about teaching in school can be dispelled.

\section{Problems existing in administrative management in agricultural institutions of higher learning}

Complex affair handling procedures and low working efficiency 
First, applications related to teaching, scientific research, reimbursement and studying abroad often needs to go through multiple levels of administrative approval. Head of various departments sign and seal such applications. The whole administrative approval process is in series connection. Different functional departments exist independently from each other. There are neither unified information approval platforms nor unified standards. As a result, administrative approval takes a long time. Second, in terms of evaluation of teachers, various functional departments require teachers to fill relevant forms according to their functions. There are too many forms of the kind. Some of them are seriously overlapped. Worse still, they have no data sharing and efficient data utilization. In this way, the working efficiency is seriously impaired and the teachers' burden is increased.

\section{Low management transparency}

At present, most institutions of higher learning in China adopt the school affairs transparency system. However, in real life, some of them keep a low transparency. First, their content transparency is inadequate. Working procedures, personnel labor distribution and relevant requirements which teachers and students need to know are not clearly and completely introduced. Second, their transparency procedures lack standards. In daily work, they often pay attention to just transparency of results but ignore transparency of the process. Third, their administrative transparency lacks an efficient supervision mechanism. In terms of whether the administrative affairs published are authentic, comprehensive and timely, an efficient supervision mechanism has not yet been put in place ${ }^{[2]}$.

Lowqualities and weak service awareness of the management team

At present, management teams in institutions of higher learning are of mixed qualities. Many management personnel do not have a professional administrative management background. They are not equipped with professional knowledge of administrative management, let alone receive any systematic administrative management education. Therefore, they cannot play their due role in their administrative management positions. Besides, administrative management personnel do not have a strong awareness of service. To them, administrative management is just some simple management task. They ignore the essence of administrative management, which is to serve students and teachers. With wrong management cognition, administrative management personnel often outmatch students and teachers. In this way, administrative management fails to play its role in the whole school management.

Lack of service evaluation and feedback

In most institutions of higher learning, evaluation of administrative management mainly features an annual top-down assessment. The assessment method has several defects. First, students and teachers are not involved in evaluating service level of management personnel. Second, lack of daily supervision.Third, lack of feedback of evaluation results. If assessment just aims to provide some outcomes and no efficient measures and advices are adopted to improve the situations based on assessment results, assessment will be meaningless.

\section{Several suggestions to improve administrative management in institutions of higher learning}

Selection of excellent management talents and establishment of a people-oriented service concept

To build a highly-qualified administrative management team in institutions of higher learning first relies on selection of excellent management talents. Before that, attention should be paid to the current status of the management team so as to find out weak points and personnel vacancy. Some irresponsible personnel should be quitted to hire some highly-qualified management personnel instead. Besides, the administrative service ability of administrative management personnel should be enhanced and their backward "bureaucracy" ideas should be removed to establish the administrative service concept of "orienting towards students and teachers and serving them." Besides, they should develop the consciousness to be a server promoting rapid development of teaching and scientific research and all-around development of students and teachers. Last but not least, they should regard service as a core element of management and give full play to the function 
of administrative management in promoting talent development. Through the service-type management style, an atmosphere aiming at serving teachers and students can be efficiently created.

Clarification of administrative management duties and improvement of working efficiency

Administrative management in institutions of higher learning attempts to enhance teaching and scientific research, transfer itself to the service type and improve its service quality and level. The overall efficiency of the administrative management should be fully upgraded ${ }^{[3]}$. Various functional departments should work with each other and establish a horizontal comprehensive service department. Through establishment of "one-stop service center," resources can be efficiently integrated. Lots of approval work can be collectively finished, thus reducing waste of time and increasing handling efficiency. Second, efficiently realize in-campus information sharing. Make full use of the network information techniques to establish the "administrative approval information platform" and the "teaching information and affairs platform" so as to achieve online processing of administrative approval, online filling of teaching information and teaching affairs and online information sharing. In this way, problems, such as long time waiting and repeated data collection, can be fundamentally solved.

Insistence on transparency of administrative management

Efficiently implement the transparency system of administrative affairs in school; insist on transparency of administrative management; and efficiently promote "sunshine administration" (meaning transparent and democratic administration). In terms of major issues related to development of schools and immediate interests of teachers and students, teachers and students should have the right to be informed and supervise. Meanwhile, in order to facilitate students and teachers to handle affairs, functional departments of administrative management must publicize personnel list, working system, workflow, service content and service scope, and improve service efficiency and quality. Efforts should be intensified to promote publicity of administrative affairs. Major issues related to school development and immediate interests of students and teachers should be issued on campus websites and the special column of schooladministrative affair on campus newspapers so that teachers and students can learn them and refer to them at any time. Public affairs and working systems related to specific department should be published on websites of respective functional departments or near their offices. At the same time, validity and timeliness of their administrative disclosure should be guaranteed, and they should receive full supervision of teachers and students, listen to their opinions and suggestions and make administrative management better serve teachers and students ${ }^{[4]}$.

Establishment of a scientific service evaluation and monitoring mechanism

To put in place a reasonable service evaluation mechanism is the innovational point of the service-type administrative management in institutions of higher learning. To pay attention to opinions of teachers and students is to help administrative management departments and their personnel to learn their shortages in their work and improve their service level. Evaluation and supervision of administrative management can be realized through end-of-term evaluation and daily supervision, respectively. For example, different functional departments of administrative management can be assessed and graded through campus websites and the major problems should be clearly described. Schools should organize specialists to summarize statistics and publicize in the whole campus. In terms of daily supervision, "President's Reception Day" and "Opinion Box" can be set up so that teachers and students can reflect their problems and suggestions in the written or oral form. These suggestions and problems reflected should be given feedbacks periodically, and included in the annual performance appraisal of administrative management department. Establishment of a scientific and reasonable service evaluation and supervision system can contribute greatly to promotion of administrative management in institutions of higher learning ${ }^{[5]}$.

\section{Conclusion}

Administrative management departments in institutions of higher learning should undertake more responsibilities, enhance service awareness of administrative management personnel, and transfer the way how service personnel handle affairs. Only in this way can efficiency of 
administrative management be greatly improved and institutions of higher learning achieve steady and sound development.

\section{References}

[1] CHEN Chen. A basic study on administrative management problems facing institutions of higher learning and countermeasures therefor[J]. Marketing Management Review, 2010 (12).

[2] XU Bo, YU Changzhi. Problems of institutions of higher learning in transforming their administrative management to the service type and countermeasures therefor[J]. Higher Agricultural Education, 2014 (06).

[3] SHEN Zhaoqian. Reflection on Problems and Solutions of Enhancing Administrative Reforms in Colleges and Universities[J]. Chinese Public Administration,2010(2).

[4] FAN Zuomin. The Reflection of Establishing Service-oriented Administrative Management Mode in Colleges[J]. Journal of Minxi Vocational and Technical College,2012(2).

[5] WU Ruikun, ZHANG Ganggang. The Problems and the Countermeasures in the Administrative Management of Colleges and Universities under New situations[J]. Journal of South China University of Technology(Social Science Edition),2013(6). 